\title{
El cuento en la prensa periódica hondureña: ensayo de una bibliografía
}

\author{
Isabel Cristina DíEZ MÉNGUEZ \\ Universidad Complutense de Madrid
}

\section{RESUMEN}

El artículo rescata una serie de cuentos hondureños publicados en la prensa periódica de Tegucigalpa a lo largo del siglo XX.

Palabras clave: cuento, Honduras, siglo XX, prensa periódica, bibliografía.

The story in the periodic Honduran press: test of a bibliography

\begin{abstract}
The article rescues a series of Honduran stories published in Tegucigalpa's periodic press along the 20 th century.
\end{abstract}

Key words: Story, Honduras, 20th century, Periodic press, Bibliography.

En el presente repertorio bibliográfico se ha pretendido rescatar, muchas veces del anonimato, una serie de cuentos insertos en la prensa periódica de Tegucigalpa, cuyas firmas pertenecen a escritores cultivadores de dicho género entre 1910 a 1999 , nacidos en Honduras.

Entre las revistas vaciadas cabe citar el Boletín de la Academia Hondureña de la Lengua, el Correo literario de Honduras, Revista Ariel, Honduras Literaria, Honduras Ilustrada, Revista Galatea, La pajarita de papel, Alcaraván, Astrolabio, Presente, Tiempo, Extra, Asociación de Prensa Hondureña, Revista del Archivo y Biblioteca Nacional, Ateneo de Honduras, Revista de la Universidad y Sectante. Para la realización del repertorio ha sido necesario consultar "in situ" la hemeroteca Nacional "Ramón Rosa" y los fondos de la Facultad de Letras de la Universidad Nacional Autónoma, ambas en Tegucigalpa (Honduras).

Las publicaciones más tempranas datan de la primera década del siglo $\mathrm{XX}$, siendo las Revista del Archivo y Biblioteca Nacional y la Revista de la Universidad de Honduras las que recogen relatos de 1905, 1907 y 1910. En septiembre y diciembre de 1905 vieron la luz en la Revista del Archivo y Biblioteca Nacional respectivamente los relatos "Fábula del crisantemo verde", de Froylán Turcios y "La Nochebuena", de Carlos Alberto Uclés; y en 1907 en la misma revista "La 
campana del reloj", de Rómulo E. Durón, "Varias cosas en un pequeño viaje", "El mendigo", ambos de Enrique Gutiérrez, y "Salomé" de Rosales Salatiel. Finalizan esta década "El domador" y Gratitud", de Froylán Turcios, publicados en la Revista de la Universidad.

Los escritores que publicaron cuentos entre sus páginas son, en diversas ocasiones, importantes personalidades de la época pertenecientes al mundo de las letras. Muchos de ellos mantuvieron una estrecha relación con el periodismo, como fundadores y directores de publicaciones periódicas, entre cuyas páginas se halla disperso el cuento hondureño. Entre ellos, se encuentra Oscar Acosta Zelaya (Tegucigalpa, 14 de abril de 1933), periodista, ensayista, poeta, narrador y dramaturgo, diplomático de carrera, actual presidente de la Academia Hondureña de la Lengua, fundador de importantes editoriales y revistas, y director de otras, entre las que se encuentran Presente y Extra. Otra de las grandes figuras vivas es Eduardo Bähr (Tela, 23 de septiembre de 1940), autor de cuentos y teatro, galardonado en 1970 con el Premio Nacional de Literatura Martínez Galindo por su libro El Cuento de la Guerra. Actualmente es el director de la Biblioteca Nacional de Honduras. Su vinculación con el periodismo queda patente como miembro del Consejo de Dirección de varias revistas de arte y letras, como Alcaraván, Presente, Astrolabio y Galatea.

Entre las páginas de las revistas y periódicos reseñados en la bibliografía de este trabajo se encuentra también figuras destacadas de principios del siglo XX como el citado Froylán Turcios (Juticalpa, 1875-San José de Costa Rica, 1943), poeta, narrador, editor, antólogo y periodista hondureño. Turcios inició el cuento del siglo XX en su país. Ministro de Estado y diplomático. Luchó contra la intervención estadounidense, lo cual le llevó a emigrar a Costa Rica (1911). Fundó en 1925 la Revista Ariel, publicación quincenal de temas variados como letras, artes, ciencia y misceláneas. La Revista Ariel fue una publicación que destacó por la conexión que mantuvo con el contexto histórico-social y por promover un arte exquisito bajo la influencia del Modernismo. Entre sus páginas publicaron Rubén Darío, Porfirio Barba-Jacob, José Enrique Rodó, Enrique Banchs, Emilio Carrere, Arturo Martínez Galindo, Augusto C. Coello, Ángel Gabinet, etc. Además Froylán Turcios dirigió el diario El Tiempo de Tegucigalpa y la revista Ateneo de Honduras. Fundó las revistas El Pensamiento (1894), Revista nueva (1902), Arte y Letras (1903) y Esfinge (1905), en la cual también estuvo presente el gusto Modernista; y en Honduras El Heraldo (1909), El Nuevo Tiempo (1911) y Boletín de la Defensa Nacional (1924). Entre las páginas de estas revistas vieron la luz por primera vez numerosos cuentos hondureños, parte de ellos del mismo Froylán Turcios. Posteriormente la mayor parte de éstos fueron publicados en los libros Hojas de Otoño (Tegucigalpa, Tipografía Nacional, 1904), Prosas nuevas (Tegucigalpa, Tipografía Nacional, 1914) y Cuentos del amor y de la muerte (Paris, Le livre libre, 1929). 
Rómulo Ernesto Durón, conocido como "Rómulo E. Durón", es otro de los grandes autores de la literatura hondureña que cultivaron el cuento a principios del siglo XX. Nació en la ciudad de Comayagüela, el 6 de julio de 1865 y falleció el 13 de agosto de 1942 en Tegucigalpa. Realizó estudios superiores en la Universidad Central de Honduras (hoy UNAH), donde obtuvo el título de Licenciado en Leyes. Posteriormente pasó a ser nombrado Juez de primera instancia en un juzgado capitalino y a continuación Magistrado en una Corte de Apelaciones. Más tarde ocupó el cargo de magistrado de la Corte Suprema de Justicia de Honduras, en dicho cargo descubriría su vocación por la educación, inclinándose impartir clases en la carrera de Leyes en la Universidad. Posteriormente fue nombrado Decano de la Facultad de Derecho de la UNAH y Rector de dicho centro de estudios superiores de 1909 a 1915. En 1909 fundó y dirigió la Revista de la Universidad. En 1915 se trasladó a la ciudad de Washington junto con notables hondureños (como el Doctor Fausto Dávila, Luis Landa Escober, Carlos Alberto Uclés, Pedro P. Amaya, Carlos Lagos).

Eliseo Pérez Cadalso (El Triunfo, Choluteca, 1920). Abogado, cuentista, político, diplomático y catedrático. Se graduó en la Universidad Nacional en 1946, realizando estudios avanzados en Colombia y Brasil. Diputado al Congreso Nacional (1948-1954), Consejero de Estado (1954-1956), Embajador en El Salvador y Nicaragua, Miembro de la Comisión Legislativa que preparó las primeras leyes laborales de Honduras (1950-1951), los proyectos de Reforma Penal (1954), la autonomía universitaria; miembro de la Comisión Jurídica Nacional encargada de laborar la legislación civil, penal, administrativa, comercial y laboral (1969-1972), Ministro de Relaciones Exteriores. En el Congreso auspició legislación referente a los derechos políticos de la mujer así como la creación de los Premios Nacionales de Arte, Literatura y Ciencia, en 1949. Compaginó los trabajos públicos con su afición por la literatura. Sus cuentos vieron la luz entre los años sesenta y setenta del siglo XX en las revistas Honduras Literaria y Extra principalmente. En 1977 le fue conferido el Premio Nacional de Literatura Ramón Rosa. De 1971 a 1973 fue Director del diario La Prensa.

Medardo Mejía (Manto, 1907-Olancho, 1981). Poeta, historiador, ensayista, narrador, periodista y académico. Premio nacional de literatura Ramón Rosa (1971). Fue otro de los escritores más destacados en el cultivo del cuento del siglo XX. En 1959 obtuvo un premio por sus Cuentos del camino, obra que según Arellano se extravió. Defensor de la democracia y los derechos del pueblo, se valió del periodismo como medio de transmisión, principalmente en la Revista Ariel que dirigía Froylán Turcios, en donde además publicó diversos cuentos en la década de los setenta. Posteriormente, en 1981 publicó varios de estos en Comizahual: leyendas, tradiciones y relatos de Honduras.

Santos Juárez Fiallos (Comayagüela, 1916-2005), fue jefe de redacción de la revista Tegucigalpa, dirigió el semanario El Tiempo y el diario Prensa Libre. Fue miembro fundador de la Asociación de Prensa Hondureña y del Pen Club de 
Honduras. Consolidó y definió el cuento psicológico en Honduras. Varios de sus cuentos vieron la luz en revistas como Honduras Literaria, Honduras Ilustrada, Presente y Extra en la década de 1960.

El Boletín de la Academia Hondureña de la Lengua fue dirigido por Luis Andrés Zúñiga. Se publicaba en los meses de marzo, julio y noviembre de cada año desde el 1 de julio de 1955. Entre sus páginas colaboraron con cuentos los hondureños Juan Ramón Martínez, Juan Escoto, Óscar Acosta, Alejandro Castro (hijo), Justiniano Vásquez, Arturo Mejía Nieto, Paca Navas de Miralda, María Trinidad del Cid, Luis Andrés Zúñiga, Lucila Gamero de Medina, Arturo Martínez Galindo, Rómulo E. Durón, Rafael Heliodoro Valle, Eliseo Pérez Cadalso, etc.

Del Correo Literario de Honduras, Revista mensual de letras, ciencias, artes y misceláneas, patrocinada por el Ministerio de Educación Pública, fue director el poeta Carlos Manuel Arita desde el 1 de junio de 1959. Entre sus páginas fue Luis Andrés Zúñiga el literato que entre los años 1960-1963 con más asiduidad publicó sus fábulas. Carlos Manuel Arita dirigió también la revista Honduras Literaria. En dicha revista participaron importantes personalidades de la época como Alejandro Castro hijo (Tegucigalpa, 1914), perteneciente a la generación literaria de 1935, periodista profesional. Destacar en tercer lugar otra de las publicaciones en las que el cuento hondureño ocupa un lugar significativo, Honduras Ilustrada, dirigida de nuevo por Carlos Manuel Arita desde 1965.

Solo se han reseñado, a modo ejemplificativo, algunas notas de algunos de los más destacados fundadores, directores y colaboradores de revistas en las que el cuento hondureño ocupó un lugar sobresaliente. De otras personalidades que cultivaron el cuento en Honduras se ofrece información bio-bibliográfica con ocasión de la publicación de sus cuentos en revistas como Honduras Literaria o el Boletín de la Academia Hondureña de la Lengua, información que ha sido reseñada a continuación a pie de página del correspondiente número de las mencionadas publicaciones periódicas.

Por último, es necesario hacer mención de la bibliografía del cuento hondureño en otras publicaciones periódicas recogida por Helen Umaña en su libro Panorama crítico del cuento hondureño (Guatemala: Editorial Letra Negra, 1999, págs. 504521), pues completa la que en este estudio se ofrece.

\section{Bibliografía del cuento en la prensa hodureña ACOSTA, Óscar.}

1970 "La trágica historia de Brinquillo", Extra, núm. 59, junio, año 5, pág. 59.

1986 "Los combatientes", Boletín de la Academia Hondureña de la Lengua, núm. 29, diciembre, año 28, págs. 205-207.

ALEMÁN, Adolfo.

1959 "El ataque", Correo literario de Honduras, núm. 2, junio, año 1, pág. 4. 
1959 "El miedo", Honduras Literaria, núm. 16-17 " noviembrediciembre, año 2, Suplemento del Boletín "Universidad de Honduras" (UNAH), pág. 2.

1963 “Coalición”, Honduras Literaria, núm. 1, enero-febrero, año 6, pág. 12.

1968 "El jarrón de los mayas", Extra, núm. 32, marzo, año 3, págs. 57 y 59-60.

1969 "El jarrón de los mayas", Honduras Ilustrada, núm. 42, enero, año 5, págs. 7 y 33 .

1970 "El pacto con el diablo", Honduras Ilustrada, núm. 60, julio, año 6 , págs. 3 y 34 .

ALMAZÁN, Marco A.

1969 "La cena de Don Pepe", Honduras Ilustrada, núm. 47, junio, año 5 , pág. 36.

ARÉVALO, Juan José.

1971 "Música maestro...", Revista Ariel, núm. 236, julio, año 13, págs. 45-48.

ARITA, Carlos Manuel.

1971 "El botijero", Honduras Ilustrada, núm. 68, marzo, año 7, págs. 6 y 35 .

1971 “El velorio", Honduras Ilustrada, núm. 69, abril, año 7, págs. 6 y 36 .

1971 "El premio de la lotería", Honduras Ilustrada, núm. 69, abril, BÄRH, Eduardo. año 7 , págs. 10-11 y 43 .

1967 "Signos. Relatos extraños: Infinito, Paréntesis, Menos e Infinito", Revista Ariel, núm. 186, abril, año 8, págs. 16-17 y 19.

1967 "Menos", Extra, núm. 26, septiembre, año 3, pág. 59.

1968 "Paréntesis", Presente, núm. 48-89, julio-agosto, año 5, pág. 13.

1968 "La niña que nace", Extra, núm. 36, julio, año 3, pág. 59.

${ }^{1} \mathrm{Al}$ comienzo del relato se ofrece esta pequeña reseña biográfica: "Adolfo Alemán nació en Tegucigalpa el $1^{\circ}$ de septiembre de 1928. Se inició en la literatura en la revista mensual Surco que editaba en Tegucigalpa su hermano, el poeta Claudio Barrera. Viajó por Europa y EE.UU. En 1952 publicó el libro de cuentos El tinajón de barro y posteriormente Tierra abierta. Publicó, además, cuentos con regularidad en La Prensa Gráfica de San Salvador y en el Diario de Nueva York y en Sucesos de Tegucigalpa".

${ }^{2}$ Al final del cuento se da la fecha de Tegucigalpa, 24 de abril de 1968. 
1968 "La niña que nace”3, Revista Ariel, núm. 201, agosto, año 10, pág. 12.

1970 "Yo sería incapaz de tirarle una piedra", Extra, núm. 64, noviembre, año 3, págs. 59-60.

1978 "El mural inconcluso", Presente, núm. 19, junio, pág. 3.

1980 "El perro", Revista Alcaraván, núm. 3, abril, pág. 26.

1998 “Malamuerte”, Revista Astrolabio, núm. 1, agosto, págs. 33-40.

BERMÚDEZ, Hernán Antonio.

1971 "Bosquejo de un poeta", Presente, núm. 83, junio, año 7, pág. 13.

1971 "Bosquejo de un poeta", Extra, núm. 36, julio, año 3, pág. 57.

BERMÚDEZ, Rubén V.

1965 "La chancleta", Revista Ariel, núm. 169, noviembre, año 7, pág. 10.

1972 "La ráfaga de ametralladora”, Extra, núm. 85, agosto, año 7, pág. 59.

BERMÚDEZ MILLA, Héctor.

1964 "Un premio", Presente, núm. 1, agosto, año 1, págs. 11-12.

1964 "Suicidio", Presente, núm. 2, septiembre, año 1, págs. 11-12.

1965 "Parábola entre dos sermones", Honduras Literaria, núm. 13, enero-febrero, año 8 , pág. 5.

1965 “Cizaña”, Presente, núm. 11, junio, año 2, págs. 17 y 24.

1965 "Pierna cruzada", Honduras Literaria, núm. 16, julio-agosto, año 8 , pág. 3 .

1966 "Entre ceja y ceja", Extra, núm. 2, junio, año 1, págs. 57-59.

1966 “Zapatos negros", Extra, núm. 15, octubre, año 2, págs. 55-57.

1967 "Biografía de una mano", Extra, núm. 24, julio, año 2, págs. 53, 55,57 y 59 .

1968 “El Rólex del Coronel”, Extra, núm. 30, enero, año 3, págs. 55, 57, 59-60.

1969 "Monólogo de Navidad", Extra, núm. 53, diciembre, año 4, págs. 57-59.

1971 "El Rólex del Coronel", Honduras Ilustrada, núm. 70, mayojunio, año 7 , págs. 2 y 41 .

1972 "Un caballo inmortal"6, Presente, núm. 100-101, noviembrediciembre, año 9, págs. 8-9.

${ }^{3}$ Al final del cuento se da la fecha de Tegucigalpa, 24 de abril de 1968.

${ }^{4} \mathrm{Al}$ final del relato se da la fecha de Tegucigalpa, 11 de marzo de 1978.

${ }^{5}$ Al final del relato se da la fecha de enero de 1980 y se indica que pertenece al libro en preparación Los cuentos de los demás. 
BORJAS, Edilberto.

1980 "Cuando llora la realidad”, Revista Alcaraván, núm. 3, abril, págs. 29-30.

BRITO, Javier Bayardo.

1969 "El síncope", Asociación de Prensa Hondureña, núm. 6-7, abril-mayo, pág. 33 .

CÁCERES LARA, Víctor.

1950 "Juana, la chica", La pajarita de papel, núm. 11, octubrediciembre, año 2, págs. 47-50.

1951 "La revolución”, La pajarita de papel, núm. 13-14, enero-marzo, año 3, págs. 87-92.

1951 "Los cascabeles", La pajarita de papel, núm. 17-18, julioseptiembre, año 3, págs. 75-80.

1951 "El velorio", La pajarita de papel, núm. 19-21, octubrediciembre, año 3, págs. 128-132.

1961 "Conejo Blanco", Honduras Literaria, núm. 32-33 (marzo-abril 1961), año 4, publicación de artes y letras del Departamento Editorial de la UNAH, Tegucigalpa (Honduras), pág. 9.

1963 "Luna de miel”, Honduras Literaria, núm. 5, septiembreoctubre, año 6 , pág. 9.

1964 "Parricidio", Honduras Literaria, núm. 8-9, marzo-abril, año 7, pág. 11.

1965 “Antolín", Honduras Literaria, núm. 13, enero-febrero, año 8, págs. 17-18.

1965 "La sierpe", Presente, núm. 8, marzo, año 2, págs. 5-6.

1965 "Don Manuel en la guerra", Presente, núm. 12, julio, año 2, págs. $13,15,26$ y 35.

1965 "El Lepasil”, Honduras Literaria, núm. 16, julio-agosto, año 8, pág. 7.

1965 "Paludismo", Honduras Ilustrada, núm. 5, septiembre, año 1, págs. 20-25.

1965 "Don Manuel y el diablo", Presente, núm. 16, noviembre, año 2, págs. 7 y 9-10.

1966 “El velorio", Presente, núm. 20-21, marzo-abril, año 3, págs. 1113.

\footnotetext{
${ }^{6}$ Al final del relato aparece la fecha de agosto de 1968.

${ }^{7}$ Víctor Cáceres Lara autor de este cuento inédito, nació en Gracias, Departamento de Lempira el 19 de febrero de 1913.

${ }^{8}$ Al final del relato se da la fecha de Comayagua, octubre 1964.
} 
1966 “La búsqueda”, Extra, núm. 14, septiembre, año 2, págs. 55-58.

1967 "Don Manuel y los entierros", Extra, núm. 19, febrero, año 2, págs. 55-57.

1969 "La revolución”, Asociación de Prensa Hondureña, núm. 4, febrero, págs. 10 y 36.

1969 "La búsqueda", Honduras Ilustrada, núm. 44, marzo, año 5, págs. 2, 34 y 36 .

1971 "La Gracia", Honduras Ilustrada, núm. 66, enero, año 7, pág. 2.

CÁRCAMO TERCERO, Hernán.

1969 "La triste historia de un cuarto de hotel"9, Presente, núm. 59, junio, año 6, págs. 5-6.

CARÍAS REYES, Marcos.

1928 "La llama”, Revista del Archivo y Biblioteca Nacional, núm. 8, enero, págs. 266-272.

1949 "Vidas rotas", La pajarita de papel, núm. 6, octubre-diciembre, año 1, págs. 64-68.

1960 "La dádiva", Correo Literario de Honduras, núm. 14, diciembre, año 2, págs. 26-27.

1970 "La familia de Jacinta", Presente, núm. 72-77, julio-diciembre, año 7, págs. 7-8.

CASTELLANOS MOYA, Horacio.

1998 "Hipertenso", Revista Astrolabio, núm. 1, agosto, págs. 43-49.

1999 "Una pequeña libreta de apuntes", Revista Galatea, núm. 2, agosto, págs. 34-38.

CASTILLO, Roberto.

1978 “Anita, la cazadora de insectos", Tiempo, núm. 2691, 4 febrero, año 8, págs. 18-19.

1978 “Subida al cielo", Tiempo, núm. 2714, 3 marzo, año 8, pág. 23.

1979 "Las moscas"10, Revista Alcaraván, núm. 1, julio, págs. 25-26.

1980 "Crónica”, Revista Alcaraván, núm. 3, abril, págs. 27-29.

1980 "Las moscas", Presente, núm. 44, julio, año 17, págs. 3-4.

1981 "El loco divino", Revista Alcaraván, núm. 6, enero, págs. 45-49.

1981 "Rómulo y Remo", Presente, núm. 51, febrero, págs. 3-5.

1982 "Tatareto", Revista Alcaraván, junio, págs. 25-26.

1983 "Figuras de agradable demencia", Revista Alcaraván, núm. 20, junio, págs. 23-28.

${ }^{9}$ Al final del relato se da la fecha de Tegucigalpa, abril 1968.

${ }^{10}$ Según se dice a pie de página de este profesor de Filosofía hondureño "el cuento que hoy publicamos forma parte de su primer libro aún inédito". 
1985 "La laguna"11 Presente, núm. 100, marzo, págs. 3-8.

1998 "El fantasma del Doctor Koestler", Revista Astrolabio, núm. 2, noviembre, págs. 38-41.

CASTILLO O., Rafael.

1988 "La vocación", Boletín de la Academia Hondureña de la Lengua, núm. 30, febrero, año 28, págs. 95-101.

CASTRO, Alejandro (hijo).

1959 "El prisionero"12, Honduras Literaria, núm. 16-17, noviembrediciembre, año 2, Suplemento del Boletín "Universidad de Honduras" (UNAH), pág. 3.

1960 "Confesiones de un niño descalzo", Correo literario de Honduras, núm. 13, octubre-noviembre, año 2, págs. 9-10.

1960 "Casas vecinas", Correo Literario de Honduras, núm. 14, diciembre, año 2, págs. 11-13.

1965 "Fascinación", Honduras Literaria, núm. 14, marzo-abril, año 8, págs. 5-6.

1966 “Armas para la libertad”, Presente, núm. 24-25, julio-agosto, año 3, págs. 5-7.

1967 “Casas vecinas”, Extra, núm. 23, junio, año 2, págs. 57-59.

1968 "Confesiones de un niño descalzo", Presente, núm. 51, octubre, año 5, págs. 9-11.

1971 "Fascinación”, Extra, núm. 68, marzo, año 6, págs. 59-60.

1977 “Jubilación”, Boletín de la Academia Hondureña de la Lengua, núm. 20, enero 1977, año 20, págs. 161-162.

1979 "El sombrero de paja", Boletín de la Academia Hondureña de la Lengua, núm. 22, enero, año 22, págs. 189-191.

1986 "Casas vecinas"13, Boletín de la Academia Hondureña de la Lengua, núm. 29, diciembre, año 28, págs. 209-214.

${ }^{11}$ Premio Plural 1984.

${ }^{12}$ Se añade la breve reseña biográfica publicada junto con el cuento al comienzo de este número de la Revista Honduras Literaria: "Alejandro Castro hijo nació en Tegucigalpa el 5 de mayo de 1914. Perteneciente a la generación literaria de 1935. Periodista profesional. Realizó sus primeros ejercicios literarios en la revista semanal Tegucigalpa, que dirigía su padre. Fue Jefe de Redacción y posteriormente Subdirector del diario El Cronista, Director del semanario La Nación, del diario Prensa Libre y del Diario Nacional que se editaba en San Pedro Sula. Con Enrique Gómez fundó la noticiera Información y Publicidad (IP) y con Virgilio Zelaya Rubí el diario hablado "Radio Tiempo". Es Premio Nacional de Periodismo y ha publicado un libro de cuentos intitulado El ángel de la balanza. Ha realizado estudios en la Facultad de Ciencias Jurídicas y Sociales de Tegucigalpa". 
CONTRERA DE DARÍO, Rafaela.

1967 “Las Ondinas”, Revista Ariel, núm. 184, febrero, año 9, págs. 6CONTRERAS, Álvaro.

9. [Firmado al final con el seudónimo Stella].

1960 "Juan Santamaría”, Correo literario de Honduras, núm. 12, agosto- septiembre, año 2 , pág. 3 .

DÍAZ LOZANO, Argentina.

1962-63 "El bandido de Sensenti", Correo literario de Honduras, núm. 18, agosto 1962- mayo 1963, año 4, págs. 22-24.

1964 "Unas horas con el diablo", Honduras Literaria, núm. 8, marzoabril, año 7, págs. 3-4.

1964 "Primer encuentro", Honduras Literaria, núm. 11, septiembreoctubre 1964, año 7, pág. 9.

1965 "Los guantes negros", Honduras Literaria, núm. 13, enerofebrero 1965, año 8, pág. 7.

1965 "Leonora”, Presente, núm. 12, julio, año 2, págs. 5 y 26.

1965 "La niña prisca", Honduras Literaria, núm. 16, julio-agosto, año 8, pág. 5.

1969 "El niño de la guitarra", Honduras Ilustrada, núm. 42, enero, año 5 , pág. 17.

DÍAZ ZELAYA, Samuel.

1965 "El Boyero", Presente, núm. 15, octubre, año 2, págs. 7-8.

1966 "Los pencos", Presente, núm. 19, febrero, año 3, pág. 3.

DURÓN, Jorge Fidel.

1970 "La casa de las tres muertes", Extra, núm. 65, diciembre, año 6, págs. 59-60.

DURÓN, Rómulo E.

1907 "La campana del reloj", Revista del Archivo y Biblioteca Nacional, núm. 13-14 mayo, año 4, págs. 431-435.

1914 "La campana del reloj", Ateneo de Honduras, núm. 4, enero, año 2, págs. 114-118.

${ }^{13}$ Según el Boletín de la Academia hondureña de la Lengua 29 (diciembre de 1986), pág. 209, Alejandro Castro h. "Nació en Tegucigalpa el 5 de mayo de 1914 y pertenece a la generación literaria de 1935. Ha sido Jefe de Redacción y Subdirector del Diario El Cronista, Director de la Revista Tegucigalpa, Jefe de Relaciones Públicas del Gobierno de Honduras. Ganador del premio "Paulino Valladares" de la Asociación de Prensa Hondureña, de la cual fue fundador. Actualmente es Presidente del Consejo de Redacción del Diario El Heraldo de Tegucigalpa. Libros publicados: El Ángel de la balanza (cuentos), Tegucigalpa, 1957”. 
1978 "La campana del reloj", Boletín de la Academia Hondureña de la Lengua, núm. 21, enero, año 21, págs. 109-113.

ESCOTO, Julio.

1967 "Los estornudos", Presente, núm. 39, octubre, año 4, págs. 3-4.

1969 "Cuestión de amor en la perversa banda de las mujeres orates...", Extra, núm. 48, agosto, año 4, págs. 57-60.

1970 "Diálogo en la casa de las siete suelas", Extra, núm. 58, marzo, año 5, págs. 59-60.

1971 "La balada del herido pájaro", Extra, núm. 67, febrero, año 6, págs. 57-60.

1971 "La banda de las mujeres pérfidas", Extra, núm. 70, mayo, año 6, págs. 55-60.

$1986^{14}$ "Cuaderno de fin de semana", Boletín de la Academia Hondureña de la Lengua, núm. 29, diciembre, año 28, págs. 201-203.

ESPINAL IRÍAS, Rigoberto.

1964 "Y las acacias florecieron", Revista Ariel, núm. 143, julio, año 6, págs. 3-4.

1964 “Un rebozo para María”, Presente, núm. 2, septiembre, año 1, Tegucigalpa (Honduras), págs. 9-10.

1965 "El infiel”, Honduras Literaria, núm. 13, enero-febrero, año 8, pág. 18.

1965 “El vendedor de almas”, Presente, núm. 8, marzo, año 2, págs. 9 y 44 .

FERRERA, Fausta.

1936 "En la hacienda El Retiro", Revista del Archivo y Biblioteca Nacional, núm. 6-7, diciembre, págs. 401-407.

1937 "Las huellas imborrables", Revista del Archivo y Biblioteca Nacional, núm. 10-11, abril-mayo, págs. 594-595.

FIGUEROA ARDÓN, Víctor.

1936-37 "Los pistos de Benito", Revista del Archivo y Biblioteca Nacional, núm. 6-7, diciembre 1936-enero 1937, págs. 407-409.

\section{FLORES, Oscar A.}

1968 "Whisky", Extra, núm. 41, diciembre, año 4, págs. 59-60.

1969 "Whisky" ", Honduras Ilustrada, núm. 43, febrero, año 5, pág. 2.

${ }^{14}$ Julio Escoto, ensayista, editor y profesor, Premio Nacional de Literatura de Honduras (1974), es autor también del cuento "Abril, antes del mediodía", con el que obtuvo el Premio Gabriel Miró 1983.

${ }^{15}$ Al final del relato se da la fecha de Tegucigalpa, noviembre de 1968. 
1969 "La puerta cerrada"16, Revista Ariel, núm. 210, mayo, año 10, págs. $15-16$ y 18.

1969 “La puerta cerrada”, Extra, núm. 46, mayo, año 4, págs. 57-59.

1969 "Aurelia"17, Extra, núm. 51, octubre, año 5, págs. 58-60.

1969 "El cuento y el estilo nuevo", Extra, núm. 62, noviembre, año 5, págs. 55-56.

1970 “Acto de heroísmo", Honduras Ilustrada, núm. 59, junio, año 6, págs. 31-36.

1970 "Final de fiesta", Extra, núm. 62, septiembre, año 6, págs. 59-60.

1973 "Primavera en otoño", Extra, núm. 92, marzo, año 7, págs. 5660.

FLORES OCHOA, Santiago.

1971 "El chantaje de los apóstoles", Extra, núm. 42, octubre, año 4, págs. 57-60.

1972 “La mujer enlutada", Extra, núm. 86, junio, año 8, págs. 59-60.

FONTANA, Jaime.

1965 "Lepazalt", Presente, núm. 17, diciembre, año 2, págs. 9-10.

1968 "Lepazalt", Extra, núm. 38, septiembre, año 4, págs. 59-63.

GAMERO DE MEDINA, Lucila.

1914 "Sor Susana", Ateneo de Honduras, núm. 10, julio, año 2, págs. 290-295.

1914 "La modelo", Ateneo de Honduras, núm. 13, octubre, año 2, págs. 400-404.

1986 "Alda", Boletín de la Academia Hondureña de la Lengua, núm. 29, diciembre, año 28, págs. 231-240.

GUTIÉRREZ, Enrique.

1907 "Varias cosas en un pequeño viaje", Revista del Archivo y Biblioteca Nacional, núm. 23-24, octubre, año 4, págs. 748-753.

1907 "El mendigo", Revista del Archivo y Biblioteca Nacional, núm. 21-22, septiembre, año 4, págs. 689-692.

GUTIÉRREZ NÁJERA, Manuel.

1969 "La balada de año nuevo", Revista Ariel, núm. 216, noviembre,

HENRÍQUEZ, Orlando. año 11, págs. 21-22.

1963 "Nacimiento último", Honduras Literaria, núm. 4, julio-agosto, año 6, pág. 15.

1966 “Nacimiento último”, Extra, núm. 12, junio, año 1, págs. 59-60.

${ }^{16}$ Del libro de cuentos Presencia del olvido de Óscar A. Flores.

${ }^{17}$ Del libro que en aquel momento el autor tenía en preparación La voz está en el viento. 
1967 "Deuda saldada", Presente, núm. 34-35, mayo-junio, año 4, págs. 4-5.

1967 "La cueva del diablo", Revista Ariel, núm. 191, septiembre, año 9, págs. 24-25.

1968 "Thanks giving day”, Extra, núm. 35, junio, año 3, págs. 57, 59 y 60.

1968 "Minicuentos", Presente, núm. 52-63, noviembre-diciembre, año 5 , pág. 6 .

1969 “Año 2050”, Extra, núm. 49, agosto, año 5, págs. 59-60.

1970 "Von Ritter", Extra, núm. 61, agosto, año 5, págs. 59-60.

1971 "Monja Blanca", Extra, núm. 71, junio, año 6, pág. 59.

1972 "Misión interplanetaria", Extra, núm. 85, octubre, año 7, págs. 58-60.

HERNÁNDEZ, Paz.

1934 "La hermana María Asunción”, Revista del Archivo y Biblioteca Nacional, núm. 12, junio, págs. 771-772.

1969 "El pago de una deuda", Extra, núm. 44, abril, año 4, págs. 5960.

JOVEL PAVÓN, Margarita Estela.

1964 "La corbata", Revista Ariel, núm. 155, septiembre, año 6, págs. 19-21.

1968 "Una propiedad en litigio", Revista Ariel, núm. 204, noviembre, año 10 , pág. 14.

1968 "El aguinaldo", Revista Ariel, núm. 205, diciembre, año 10, págs. 9-10.

1969 "Naides se va", Revista Ariel, núm. 207, febrero, año 11, págs. 16-18.

JUÁREZ FIALLOS, Santos.

1963 "El milagro", Honduras Literaria, núm. 3, mayo-junio, año 6, págs. 2-3.

1964 "Demasiado tarde", Honduras Literaria, núm. 7, enero-febrero, año 7 , págs. 7-8.

1965 "La mujer en el ómnibus”, Presente, núm. 10, mayo, año 2, págs. 9 y 11.

1965 "El hombre que no quería hablar", Presente, núm. 16, noviembre, año 2, págs. 3-4 y 10.

1967 "Cuento de Navidad", Extra, núm. 20, marzo, año 2, págs. 5758.

1967 "El talento", Extra, núm. 29, diciembre, año 3, págs. 59-69.

1968 "La doble pena", Extra, núm. 37, agosto, año 4, págs. 67-681.

1969 "El hombre que no quería hablar", Extra, núm. 43, febrero, año 4, págs. 59-60. 
1969 "El hombre de la americana", Honduras Ilustrada, núm. 45, abril, año 5, pág. 2.

1970 "La muerte viajaba en coche" (inédito), Extra, núm. 55, febrero, año 5, pág. 59.

LAIINEZ DE BLANCO, Mercedes.

1937 "Curada", Revista del Archivo y de la Biblioteca Nacional, núm. 10-11, abril-mayo, año 15, págs. 592-593.

LANDA BLANCO, Yanvario.

1967 "Cuatro días en un hospital", Extra, núm. 29, diciembre, año 3, págs. 23 y 25.

1967 "Como era el abuelo", Extra, núm. 21, abril, año 2, págs. 53 y 55.

1967 “Clarividente o farsante?”, Extra, núm. 27, octubre, año 3, págs. 33 y 35 .

LOBO, Hostilio.

1972 "Este es el cuento del hombre y los monos", Extra, núm. 84, julio, año 7, págs. 59-60.

LÓPEZ PINEDA, Julián.

1914 "El hombre de los siete misterios", Ateneo de Honduras, núm. 13, octubre, año 2, págs. 382-386.

MARTÍNEZ, Juan Ramón.

1985 "El regalo de la muerte y de la vida", Boletín de la Academia MARTÍNEZ GALINDO, Arturo. Hondureña de la Lengua, núm. $28^{18}$, julio, año 27, págs. 75-81.

1936-37 "Aquella noche", Revista del Archivo y Biblioteca Nacional, núm. 6-7, diciembre-enero, págs. 411-412.

1952 “Aurelia San Martín”, La pajarita de papel, núm. 22-24, eneromarzo, año 4, págs. 97-103.

1952 "Desvarío", La pajarita de papel, núm. 25-27, abril-junio, año 4, págs. $78-83$.

1959 "La pareja y uno más", Honduras Literaria, núm. 16-17 ${ }^{19}$, noviembre-diciembre, año 2, Suplemento del Boletín "Universidad de Honduras" (UNAH), págs. 9-10.

${ }^{18}$ Al final del cuento se da la fecha de escritura Tegucigalpa, D.C., diciembre/84febrero/85.

${ }^{19}$ De Arturo Martínez Galindo se ofrece la siguiente reseña biográfica al inicio de este cuento: "Poeta, periodista y cuentista hondureño. Se graduó en Derecho. Viajó por EE.UU. Es autor del libro Sombras. Martínez Galindo incorporó el cuento urbano, de ciudad, a la narrativa nacional, dotándolo de una técnica hasta entonces desconocida. Fue director del 
1959 "La tentación”, Correo Literario de Honduras, núm. 7, diciembre, año 1, pág. 17.

1962 "La tentación", Boletín de la Academia Hondureña, núm. 8, septiembre, año 7, págs. 91-93.

1964 "La tentación”, Revista Ariel, núm. 154, agosto, año 6, pág. 18.

1967 "La tentación", Honduras Ilustrada, núm. 47, abril, año 3, pág. 6.

1986 "La tentación”, Boletín de la Academia Hondureña de la Lengua, núm. 29, diciembre, año 28, págs. 245-247.

1971 "El padre Ortega", Revista Ariel, núm. 235, junio, año 12, págs. 27-29.

1977 "Un regalo de Navidad", Sectante, núm. 2, julio-diciembre, año MEJÍA, Medardo. 2, págs. 5, 2, 5 y 10 .

1970 "El entierro"20, Revista Ariel, núm. 227, octubre, año 12, pág. 6.

1971 "Doña Apolinaria”, Extra, núm. 72, julio, año 7, págs. 59-60.

1971 "Acta de Independencia" [Relato proletario] ${ }^{21}$, Revista Ariel, núm. 238, septiembre, año 13, págs. 5-8.

1971 "El día de Mamisaca" [Relatos olanchanos], Revista Ariel, núm. 238, septiembre, año 13, págs. 9-12.

1971 "En el higueral"22, Revista Ariel, núm. 241, diciembre, año 12, págs. 25-26.

1972 “La silla vieja”, Revista Ariel, núm. 243, marzo, año 14, págs. 910.

1972 "El pirata aéreo", Revista Ariel, núm. 245, mayo, año 13, pág. 4.

1972 “Aquí así es...", Revista Ariel, núm. 248, agosto, año 14, pág. 31.

1972 “Aquí así es...”, Extra, núm. 88, noviembre, año 8, pág. 59.

1972 "Lolie" [Relato regional], Revista Ariel, núm. 252, diciembre, año 14, págs. 7-8.

1973 “Copérnico", Revista Ariel, núm. 253, febrero, año 15, págs. 1314.

diario El Norte de San Pedro Sula (Honduras) y popularizó los seudónimos de Armando Imperio y Julio Sol en la prensa nacional. Murió salvajemente en la costa norte del país antes de cumplir los cuarenta años por caciques políticos de la dictadura".

${ }^{20} \mathrm{Al}$ final del relato se da la fecha de Tegucigalpa, 17 de enero de 1926.

${ }^{21}$ Al final del relato se da la fecha de Tegucigalpa, $1^{\circ}$ de septiembre de 1971.

${ }^{22}$ Al final del relato se da la fecha de Catacamas, 5 de enero de 1970. 
MEJÍA NIETO, Arturo.

1949 "La culebra", La pajarita de papel, núm. 6, octubre-diciembre, año 1, págs. 73-77.

1960 "Cuestión de honor", Honduras Literaria, núm. 28-29, noviembre-diciembre, año 3, págs. 15-16.

1961 “El Patrón”, Honduras Literaria, núm. 30-31, enero-febrero, año 4, págs. 15-16.

1963 "Los hermanos", Honduras Literaria, núm. 2, marzo-abril, año 6, págs. 5-6.

1963 "El ajusticiado", Honduras Literaria, núm. 4, julio-agosto, año 6, págs. 5-6.

1963 "El náufrago", Honduras Literaria, núm. 5, septiembre-octubre, año 6, págs. 17-18.

1965 "Codicia", Honduras Literaria, núm. 13, enero-febrero, año 8, págs. 13-14.

1965 "La arrepentida", Honduras Literaria, núm. 14, marzo-abril, año 8, págs. 3-4 y 6.

1966 "La culebra”, Extra, núm. 10, mayo, año 1, págs. 39-43.

1967 "Es lo que uno no comprende", Extra, núm. 28, noviembre, año 3 , págs. 59-60.

1969 "El desterrado", Extra, núm. 42, enero, año 4, págs. 59-60.

1969 "Ese hombre que pasó es tu padre" (inédito, enviado desde Buenos Aires, 1969), Extra, núm. 52, noviembre, año 4, págs. 59-60.

1970 "Muchacho tonto", Extra, núm. 54, enero, año 5, págs. 57-59.

1970 "La dueña del cielo" (inédito), Extra, núm. 57, abril, año 5, págs. 59-60.

1970 "El solterón”, Honduras Ilustrada, núm. 59-60, junio-julio, año 6, págs. 59-60.

1970 "La pierna ortopédica", Extra, núm. 70, julio, año 5, págs. 57-59.

1970 "El ajusticiado", Extra, núm. 63, octubre, año 5, págs. 59-60.

1971 “Aceite de Castor”, Extra, núm. 66, enero, año 6, págs. 59-60.

1971 “Tres niños", Extra, núm. 69, abril, año 6, págs. 57-60.

1972 "Aceite de Castor", Boletín de la Academia Hondureña de la Lengua, núm. 15, noviembre, año 15, págs. 79-83.

1972 "El ajusticiado", Boletín de la Academia Hondureña de la Lengua, núm. 15, noviembre, año 15, págs. 73-77.

1986 "El escritor", Boletín de la Academia Hondureña de la Lengua, núm. 29, diciembre, año 28, págs. 217-219.

MOLINA, Juan Ramón.

1949 "Profética", La pajarita de papel, núm. 4, agosto-septiembre, año 1, págs. 66-67. 
1949 "El Chele", La pajarita de papel, núm. 4, agosto-septiembre, año 1, págs. 68-70.

1959 "El corneta", Boletín de la Academia Hondureña, núm. 6, julio, año 5, págs. 101-104.

1960 "La niña de la patata", Correo Literario de Honduras, núm. 11, julio, año 2, pág. 5.

1978 "La niña de la patata", Boletín de la Academia Hondureña de la Lengua, núm. 21, enero, año 21, págs. 105-107.

MORRIS, Andrés.

1981 "La piedra pulida”, Revista Alcaraván, abril, pág. 35-36.

MOYA POSAS, David.

1963 "Cuento de Navidad", Honduras Literaria, núm. 2, marzo-abril, año 6, pág. 14.

1972 “Cuento de Navidad”, Extra, núm. 89, diciembre, año 7, págs. 59-60.

NÁJERA DE AYALA, Fausta.

1972 "Aquel muchacho", Revista Ariel, núm. 242, diciembre, año 13, págs. 5-28.

NAVAS DE MIRALDA, Paca.

S.a. $\quad$ "Cruel experiencia", Revista del Archivo y Biblioteca Nacional, núm. 12, pág. 666.

1961 "Gente de la calle", Correo literario de Honduras, núm. 15, enero-febrero, año 3, págs. 18-19.

1971 “Gente de la calle”, Honduras Ilustrada, núm. 67, febrero, año 7, pág. 6.

1986 "El destino", Boletín de la Academia Hondureña de la Lengua, núm. 29, diciembre, año 28, págs. 221-224.

OCHOA, Leandro B.

1966 "La mocha", Revista Ariel, núm. 181, agosto, año 8, págs. 1320.

1966 "La poza de la sirena", Revista Ariel, núm. 181, noviembre, año 8, pág. 20.

OQUELÍ, Arturo.

1960 "Mi patrimonio con la tía de mi esposa", Correo literario de Honduras, núm. 12, agosto-septiembre, año 2, págs. 6-7.

1961 "Las mujeres como los santos, hacen milagros", Correo literario de Honduras, núm. 16, marzo-noviembre, año 3, págs. 14-16.

1961-62 "La muerte del compadre García", Correo literario de Honduras, núm. 17, diciembre-julio, año 3, págs. 22-23.

ORTEGA, Miguel R.

1986 "La llave", Boletín de la Academia Hondureña de la Lengua, núm. 29, diciembre, año 28, págs. 241-244. 
1978 "Aquellas manos", Boletín de la Academia Hondureña de la Lengua, núm. 21, enero, año 21, págs. 103-104.

OVIEDO, Jorge Luis.

1972 "De mediodiabajo", Presente, núm. 100-101, noviembrediciembre, año 9, págs. 3-5.

1982 "La cara del espejo", Revista Alcaraván, octubre, pág. 31.

PALACIOS M., José María.

1968 "A la cárcel volveré... sólo muerto”, Revista Ariel, núm. 204, noviembre, año 10, págs. 11-13.

1969 "La coyota", Revista Ariel, núm. 212, julio, año 10, págs. 19-21.

PAREDES GONZALES, Salomón.

1960 "Almas incomprendidas", Correo literario de Honduras, núm.

PAZ HERNÁNDEZ. 101, mayo, año 2 , págs. 38-39.

1968 "Los mejores cuentos hondureños: El pago de una deuda", Asociación de Prensa Hondureña, núm. 1, noviembre, págs. 3940.

PAZ PAREDES, Rafael.

1963 "La muerte del sonido", Honduras Literaria, núm. 5, septiembre-octubre, año 6, pág. 3.

1965 "Tiempo para esperar" ${ }^{23}$, Presente, núm. 8, marzo, año 2, pág. 3.

1965 "Retrato de una mujer antigua", Presente, núm. 9, abril, año 2, pág. 3.

1967 “El guarda Téllez”, Extra, núm. 25, agosto, año 3, págs. 55, 57 y 59.

1973 "El anillo de bodas", Extra, núm. 97, agosto, año 7, págs. 37-39, $41-42$ y 50.

PECK FERNÁNDEZ, Federico.

1965 "Vaqueando", Revista Ariel, núm. 165, julio, año 7, págs. 12-13. PÉREZ CADALSO, Eliseo.

1961 "Sal y pimienta de Juan Namasigüe"24, Honduras Literaria, núm. 30-31, enero-febrero, año 4, pág. 2.

${ }^{23}$ Al final del relato se da la fecha de Tegucigalpa, 23 de enero de 1965.

${ }^{24}$ Se recoge la siguiente reseña biográfica de autor, publicada en Honduras Literaria junto al cuento: "Eliseo Pérez Cadalso (El Triunfo, Departamento de Cholutec). Fue abogado y notario Público. Realizó, además, cursos sobre Derecho Internacional Público del Trabajo y Asuntos Económicos en Bogotá. En Rio de Janeiro se diplomó en Administración por la Fundación Estudio Vargas en 1957. Ha sido diputado en el Congreso Nacional, Secretario de la Sociedad de Abogados, Secretario de la Asociación de Prensa Hondureña, 
1963 "Sufragio libre", Honduras Literaria, núm. 2, marzo-abril, año 6, págs. 3-4.

1963 "El policía de la esquina", Honduras Literaria, núm. 4, julioagosto, año 6, pág. 17.

1963 "Chabelo", Honduras Literaria, núm. 5, septiembre-octubre, año 6, págs. 5-6.

1964 "El tunco creuncio", Honduras Literaria, núm. 7, enero-febrero, año 7, págs. 13-14.

1964 "El primer diente", Honduras Literaria, núm. 8, marzo-abril, año 7 , pág. 7 .

1965 "La Giralda", Honduras Literaria, núm. 13, enero-febrero, año 8, págs. 14-15.

1965 "El Rey del Tango", Honduras Literaria, núm. 14, marzo-abril, año 8 , págs. 15-17.

1965 "Peces de colores", Honduras Ilustrada, núm. 5, diciembre, año 1, págs. 25-27.

1966 "Pozo de malacate", Extra, núm. 13, agosto, año 2, págs. 55 y 57-58.

1966 "Cosas de machos", Extra, núm. 16, noviembre, año 2, págs. 5558.

1967 "Los caminos de la carne" Revista Ariel, núm. 191, septiembre, año 9, págs. 14-15.

1969 "Diplomático", Extra, núm. 47, junio, año 4, págs. 59-60.

1973 “Bambino", Extra, núm. 93, abril, año 7, págs. 59-60.

miembro de la Comisión Nacional de Administración dependiente de la ESAPAC, asesor del Ministerio de Asuntos Exteriores en la Segunda Reunión de Organización de Estados Centroamericanos (ODECA) celebrada en Managua en 1953, Delegado de Honduras en la Reunión del Consejo Interamericano de Jurisconsultos celebrado en México en enero de 1956 y catedrático de Derecho Internacional Público, Sociología y Criminología de la Facultad de Ciencias Jurídicas y Sociales de la Universidad Nacional Autónoma de Honduras. Tiene dos libros de poesía: Vendimia y Jicaral, el primero publicado en Tegucigalpa en 1943 y el segundo en Colombia en 1947. Ha publicado además un ensayo intitulado Guillén Zelaya en el Neomodernismo de América y Poesía y Muerte en el camino de Martí de 1933. En diciembre de 1959 el Gobierno de Guatemala editó por su cuenta su libro de cuentos Achiote de la comarca, ganador del Segundo Premio de la rama de cuento en el Certamen Nacional Permanente de Ciencias, Letras y Bellas Artes de 1958, obra que fue presentada con el pseudónimo de Jesús Omán del castillo. Desempeñó el cargo de Director de Asuntos Culturales de la Organización de Estados Centroamericanos (ODECA), con gran éxito". 
1975 “Camotillo", Revista Ariel, núm. 274, enero-febrero, año 16, págs. 5-6.

1975 "Diplomático", Revista Ariel, núm. 275, marzo, año 17, págs. 27-28.

1988 "Dos guitarras", Boletín de la Academia Hondureña de la Lengua, núm. 30, febrero, año 28, págs. 93-94.

PINEDA, Ricardo.

1972 "Tragedia de Naco"25, Revista Ariel, núm. 252, diciembre, año 14, págs. 13-14. [Dedicado al Dr. Rómulo E. Durón].

RAMOS, María Eugenia.

1969 "Quink"26, Revista Ariel, núm. 211, junio, año 10, pág. 25.

REYES, José Antonio.

1967 "La casita gris" [cuento navideño], Revista Ariel, núm. 194,

RIVERA, Coronado. diciembre, año 9 , págs. 4-5.

1960 "El espanto del cementerio" [Relato del terruño], Correo literario de Honduras, núm. 14, diciembre, año 2, pág. 32.

TRINIDAD DEL CID, María.

1986 "Las abejas de la negra vieja", Boletín de la Academia Hondureña de la Lengua, núm. 29, diciembre, año 28, págs. 225-228.

ROMERO, José.

1964 "La oración de mi madre", Revista Ariel, núm. 158, diciembre, año 6 , págs. 26-27.

ROSA, Marco Antonio.

1964 "Mensaje navideño", Presente, núm. 5, diciembre, año 1, págs. 6-7 y 44.

ROSALES ABELLA, Rodolfo.

1968 "El rancho", Presente, núm. 50, septiembre, año 5, pág. 5 y 35.

ROSALES SALATIEL.

1907 "Salomé", Revista del Archivo y Biblioteca Nacional, núm. 1718 , julio, año 4, págs. 471-572.

1927 "La botija", Revista del Archivo y Biblioteca Nacional, núm. 2, julio, págs. 21-23.

${ }^{25}$ Al final del relato se da la fecha de Tegucigalpa, 13 de marzo de 1896, Revista de la juventud Hondureña, núm. 46.

${ }^{26}$ Al final del relatos se da noticia de la temprana edad de María Eugenia Ramos, hija del profesor Ventura Ramos, y de su precocidad literaria. 
1927 "La botija", Revista del Archivo y Biblioteca Nacional, núm. 3, agosto, págs. 20-24.

RUBIO ZACAPA, José.

1969 "Aventura sonambulesca", Asociación de Prensa Hondureña, núm. 3, enero, págs. 3 y 42 .

1969 "Insecto azteca", Asociación de Prensa Hondureña, núm. 3, enero, pág. 37.

SALVADOR, Francisco.

1966 "Tiempo sin lucha", Extra, núm. 15, octubre, año 2, págs. 27 y 29.

1968 "Megatón"27, Presente, núm. 45, abril, año 5, págs. 9-14 y 44.

1969 "El toro negro" (inédito), Extra, núm. 50, septiembre, año 5, págs. 57-59.

1969 "El toro negro", Revista Ariel, núm. 215, octubre, año 11, págs. 21-23.

SERRANO, Augusto.

1999 "Siroco"28, Revista Galatea, núm. 3, noviembre, págs. 22-29.

SOLOGAISTOA, J. Cruz.

1914 "El triunfo del tacto", Ateneo de Honduras, núm. 4, enero, año 2, págs. 112-113.

1914 "Las bibliotecas que se miran desde la calle", Ateneo de Honduras, núm. 8, mayo, año 2, págs. 244-246.

SOSA, Roberto.

1998 "Vuelta de campana" [A Rodolfo Pastor Fasquelle], Revista Astrolabio, núm. 1, agosto, págs. 30-32.

TORUÑO, Juan Felipe.

1949 "Cáscara de naranja", La pajarita de papel, núm. 6, octubrediciembre, año 1, págs. 69-72.

TRAVIESO, Jorge Federico.

1977 "La torta de Navidad", Tiempo, núm. 2621, noviembre, año 7, pág. 16.

1998 "La única", Revista Astrolabio, núm. 2, noviembre, págs. 42-51.

1999 "Todo un miércoles (Fragmento)", Revista Galatea, núm. 2, agosto, págs. 39-42.

TRÓCHEZ, Raúl Gilberto.

1958 "El magnate que aborreció los gatos", Honduras Literaria, núm. 66 , septiembre, año 1, págs. 8-18.

${ }^{27}$ Al final del relato se da la fecha de Tegucigalpa, diciembre de 1967.

${ }^{28}$ Fragmento del capítulo 13 de su novela por entonces inédita Viento de la memoria. 
1963 "Huyendo de la justicia", Honduras Literaria, núm. 5, septiembre-octubre, año 6, pág. 15.

1964 "Malditos periquitos", Honduras Literaria, núm. 7, enerofebrero, año 7, pág. 17.

1968 "La pistola", Revista Ariel, núm. 200, julio, año 10, pág. 22.

1968 “Qué haremos con 10 centavos?”, Revista Ariel, núm. 203, octubre, año 10, págs. 22-23.

1969 "Nancy", Asociación de Prensa Hondureña, núm. 3, enero, págs. 6 y 39.

TURCIOS, Froylán.

1905 "Fábula del crisantemo verde", Revista del Archivo y Biblioteca Nacional, núm. 21 septiembre, año 2, págs. 639-640.

1910 "El domador", Revista de la Universidad, núm. 5, mayo, año 2, pág. 320.

1910 "Gratitud", Revista de la Universidad, núm. 8, agosto, año 2, pág. 517.

1923 "El caso de Ernesto", Ateneo de Honduras, núm. 46, marzo, año 11, págs. 1701-1703.

1927 "El parricida", Revista del Archivo y Biblioteca Nacional, núm. 4, septiembre, págs. 117-119.

1933 "Un drama campestre", Revista del Archivo y Biblioteca Nacional, núm. 2, agosto, págs. 116-117.

1962 "Aventura galante", Boletín de la Academia Hondureña, núm. 8, septiembre, año 7, pág. 77 .

1962 "Katie: relato de un muchacho de Brooklyn", Boletín de la Academia Hondureña, núm. 8, septiembre, año 7, págs. 75-76.

1965 "La mejor limosna", Revista Ariel, núm. 165, julio, año 7, pág. 11.

1967 "La mujer ideal"29, Revista Ariel, núm. 191, septiembre, año 9, pág. 23.

1968 “Katie”, Presente, núm. 50, septiembre, año 5, pág. 13.

1973 "Cuentos del amor y de la muerte: Las garras del tigre, El parricida y La mejor limosna", Revista Ariel, núm. 254, marzo, año 13, págs. 24-26.

1973 "Idilio roto", Revista Ariel, núm. 255, abril, año 13, pág. 21.

TURCIOS, Rafaela.

1932"El canario de Sor María”, Revista del Archivo y Biblioteca Nacional, núm. 3, septiembre, págs. 105-107.

${ }^{29}$ Al final del relato se da la fecha de abril de 1938. 
UCLÉS, Carlos Alberto.

1905 "La Nochebuena", Revista del Archivo y Biblioteca Nacional, núm. 4, diciembre, año 2, págs. 120-121.

1964 "La Nochebuena", Revista Ariel, núm. 158, diciembre, año 6, pág. 9.

VALDESPINO, Luis ${ }^{30}$.

1986 “Añoranzas”, Boletín de la Academia Hondureña de la Lengua, núm. 29, diciembre, año 28, págs. 248-252.

VALLADARES, Paulino.

1970 "Inmortal"31, Revista Ariel, núm. 221, abril, año 12, págs. 27-28.

1970 "Ensueño", Revista Ariel, núm. 223, junio, año 11, pág. 7.

1970 "La vejez", Revista Ariel, núm. 226, septiembre, año 12, págs. $17-18$.

1972 “Ensueño", Extra, núm. 86, septiembre, año 7, pág. 59.

VALLE, Rafael Heliodoro.

1936 "El tuerto Acero", Revista del Archivo y Biblioteca Nacional, núm. 8, febrero, págs. 502-503.

1973 "La limosna de un bandido", Extra, núm. 91, febrero, año 7, págs. 59-60.

1991 "M'hijito", Boletín de la Academia Hondureña de la Lengua, núm. 32, septiembre, año 32, págs. 72-75.

VÁSQUEZ, Justiniano.

1967 “Toño Merlo", Extra, núm. 27, octubre, año 3, págs. 53, 55, 57 y 59.

1970 "Cingo" (narración inédita del ganador del Premio ESSO de Cuento), Extra, núm. 56, marzo, año 5, pág. 59.

1976 "Míreme la seña", Revista Ariel, núm. 286, marzo, año 17, pág. 25.

1986 "Silencio solidario", Boletín de la Academia Hondureña de la Lengua, núm. 29, diciembre, año 28, págs. 215 a las 216.

VIANA, Edmar C.

1964 "Tierra moribunda", Honduras Literaria, núm. 12, noviembrediciembre, año 7, pág. 20.

1965 "La ciudad y la milpa", Honduras Literaria, núm. 13, enerofebrero, año 8, pág. 19.

30 Véase la biografía de este autor en RIAÑO JAUMA, Ricardo. 1986. "Luis Valdespino", Boletín de la Academia Hondureña de la Lengua, núm. 29, diciembre, año 28, págs. 253-255.

${ }^{31}$ Relato publicado en el diario La Estrella, de Nicaragua en 1908. 
1965 "Una noche de arena", Honduras Literaria, núm. 16, julioagosto, año 8, pág. 20.

1966 “Alas de madera”, Extra, núm. 17, diciembre, año 2, págs. 5760.

1967 "La primera esperanza”, Extra, núm. 21, abril, año 2, págs. 5758.

1973 "Noche de piedra", Extra, núm. 97, agosto, año 7, págs. 43-44 y 46-50.

VIANA, Max F.

1968 "Barquitos de ilusión" [Para el distinguido literato Medardo Mejía], Revista Ariel, núm. 202, septiembre, año 10, págs. 2728.

1973 "Perro sin dueño", Revista Ariel, núm. 262, noviembre, año 13, pág. 23.

1974 "La leyenda del duende", Revista Ariel, núm. 272, noviembre, año 16, págs. 16-17.

VILLEDA BERMÚDEZ, Rubén.

1972 "La ráfaga de ametralladora", Extra, núm. 85, agosto, año 6, pág. 59.

WAINWRIGHT, Juan Pablo.

1975 "Doctor general"32, Revista Ariel, núm. 274, enero-febrero, año 16 , págs. 7-8.

ZACAPA RUBIO, José.

1969 "La falsa limosna", Asociación de Prensa Hondureña, febrero, págs. 13-14.

ZAPATA, Fausto.

1968 "Vuelta", Extra, núm. 30, enero, año 3, págs. 39, 41, 43, 45, 47 y 49 .

ZÚÑIGA, Luis Andrés.

1960 "Martín Pescador y sus rentas" [Fábula hondureña], Correo literario de Honduras, núm. 11, 1 julio, año 2, págs. 17-18.

1960 "Un fiesta en la corte", Correo literario de Honduras, núm. 12, agosto- septiembre, año 2, págs. 4-5.

1960 "El gran equilibrista" [Fábula hondureña], Correo literario de Honduras 13, octubre-noviembre, año 2, págs. 12-14.

1960 "El conejo hablador" [Fábula hondureña], Correo literario de Honduras, núm. 14, diciembre, año 2, págs. 23-24.

\footnotetext{
1934.

${ }^{32}$ Publicado en Tela, en 1925 y reproducido por Diario del Norte, núm. 4339, La Ceiba,
} 
1962-63 "El señor intendente" [Fábula hondureña], Correo literario de Honduras, núm. 18, agosto- mayo, año 4, págs. 26-28.

1986 "El águila y el sapo", Boletín de la Academia Hondureña de la Lengua, núm. 29, diciembre, año 28, págs. 229-230.

\section{Ficha técnica de las revistas consultadas}

\section{Boletín de la Academia Hondureña de la Lengua}

Responsables: Luis Andrés Zúñiga (Director), Jesús Aguilar Paz (Administrador). Periodicidad: Publicación trimestral, en los meses de marzo, julio y noviembre de cada año. Número 1 de julio de 1955. Tegucigalpa, Departamento de Francisco Morazán, Honduras.

Consultado: Años 1972, 1977-1979, 1985-1986, 1988, 1985 y 1991.

Ubicación: Hemeroteca Nacional "Ramón Rosa”, signatura: 25.

\section{Correo literario de Honduras}

Revista de letras, ciencias, artes y misceláneas. Patrocinada por el Ministerio de Educación Pública.

Responsables: Carlos Manuel Arita (Director).

Periodicidad: Publicación mensual, número 1 de junio de 1959. Posteriormente bimensual (en 1960) y anual (marzo-noviembre 1961; diciembre 1961-julio 1962; agosto 1962-mayo 1963). Tegucigalpa, Departamento de Francisco Morazán, Honduras.

Consultado: Años 1959-1963.

Ubicación: Hemeroteca Nacional "Ramón Rosa", signatura: 4.

Revista Ariel

Responsable: Primera etapa (22 de octubre de 1913-1937) Froylan Turcios (Fundador) y Arturo Martínez Galindo (Directores). Segunda etapa (1937-1943) Foylan Turcios (Director). Tercera etapa (1943-1976) Medardo Mejía (Director).

Periodicidad: Publicación quincenal (primera etapa), Tegucigalpa, Departamento de Francisco Morazán, Honduras. Publicación quincenal (segunda etapa), San José, Costa Rica. Publicación mensual (tercera etapa), Tegucigalpa M.D.C., Departamento de Francisco Morazán, Honduras.

Consultado: Años 1964-1976.

Ubicación: Universidad Nacional Autónoma de Honduras (UNAH).

\section{Honduras Literaria}

Periodicidad: Publicación bimestral del Departamento Editorial de la Universidad Nacional Autónoma de Honduras, Tegucigalpa, Imprenta La República.

Consultados: Años 1958 (año 1)-1965. 
Ubicación: Universidad Nacional Autónoma de Honduras (UNAH), signatura: 800.- Hemeroteca Nacional "Ramón Rosa", signatura: 2.

\section{Honduras Ilustrada}

Responsables: Carlos Manuel Arita (Director), Margarita Villeda de Arita (Administradora) y Geraldina Arita de Villeda (encargada de publicidad y anuncios). Periodicidad: Publicación mensual, número 1 de agosto de 1965. Tegucigalpa, Departamento de Francisco Morazán, Honduras.

Consultados: Años 1965, 1967, 1969-1971.

Ubicación: Universidad Nacional Autónoma de Honduras (UNAH), signatura: 800.- Hemeroteca Nacional "Ramón Rosa", signatura: 4.

\section{Revista Galatea}

Revista de Arte y Literatura.

Responsables: Hernán Antonio Bermúdez y Rigoberto Paredes (Directores), Eduardo Bärh (Co-director y Comité de Redacción), Evaristo López Rojas (Editor), Roberto Castillo (Comité de Redacción), Mario Posas (Comité de Redacción), Rodolfo Pastor Fasquelle (Comité de Redacción), Horacio Castellanos Moya (Comité de Redacción), Héktor Varela (Diagramación). Publicada en Litografía López con el patrocinio del Ingeniero Ivis López, Presidente del Grupo Capital.

Periodicidad: Publicación trimestral.

Consultado: Año 1999, número 2 (agosto) y número 3 (noviembre). Tegucigalpa, Departamento de Francisco Morazán, Honduras.

Ubicación: Universidad Nacional Autónoma de Honduras (UNAH), signatura: 344.09 .

\section{La pajarita de papel}

Órgano del PEN Club de Honduras.

Responsables: Alfonso Teja Zabra (Secretario General), Humberto López Villamil (Secretario ejecutivo a cargo de la publicación) y Víctor Castañeda (Secretario de actas).

Periodicidad: Publicación bimensual. Número 1 de enero-febrero de 1949. Tegucigalpa, Departamento de Francisco Morazán, Honduras.

Consultado: años 1949-1953.

Ubicación: Hemeroteca Nacional "Ramón Rosa", signatura: 6.

\section{Alcaraván}

Revista de Arte y Literatura.

Responsables: Eduardo Bärh (Co-director), Hernan Castillo, Rigoberto Paredes, bajo el patrocinio del Comité Ejecutivo de la Federación de Estudiantes de la 
Universidad de Honduras (F.E.U.H.) presidido por Arturo Echenique. Tegucigalpa (Honduras), Ciudad Universitaria, Editorial Universitaria.

Periodicidad: Dos o tres veces por año. Número 1 de julio de 1979. Tegucigalpa, Departamento de Francisco Morazán, Honduras.

Consultado: Años 1979-1983.

Ubicación: Universidad Nacional Autónoma de Honduras (UNAH), signatura: 800.

\section{Astrolabio}

Revista de Arte y Literatura.

Responsables: Eduardo Bärh (Co-director), Víctor Meza (Editor) Hernán Antonio Bermúdez (Coordinador Editorial), Roberto Castillo (Consejo de redacción), Rigoberto Paredes (Consejo de redacción). Publicación del Centro de Documentación de Honduras (CEDOH).

Periodicidad: Publicación bianual. Tegucigalpa, Departamento de Francisco Morazán, Honduras.

Consultado: Primer número de agosto de 1998 y segundo número de noviembre de 1998.

Ubicación: Universidad Nacional Autónoma de Honduras (UNAH), signatura: 300.

\section{Presente}

Revista de Arte y Letras de Centroamérica.

Responsables: Óscar Acosta y Roberto Sosa. Fundada por Óscar Acosta.

Periodicidad: Publicación mensual. Número 1 de agosto de 1964. Tegucigalpa, Departamento de Francisco Morazán, Honduras. Editorial Iberoamericana.

Consultado: Años 1964 (año 1)-1970, 1972, 1978, 1980-1981 y 1985.

Ubicación: Universidad Nacional Autónoma de Honduras (UNAH), signatura: 800.- Hemeroteca Nacional "Ramón Rosa", signatura: 21.

\section{Diario El Tiempo}

Responsables: Edmond L. Bográn (Director general), Manuel Gamero (SubDirector), Ramón Oquelí (Director en Tegucigalpa), Manuel J. Lara (Gerente).

Periodicidad: Publicación diaria. Número 1 del 7 de noviembre de 1970. San Pedro Sula, Departamento de Cortés, Honduras.

Consultado: Años 1977 (año 7) y 1878 (año 8).

\section{Extra}

Revista mensual de la vida nacional.

Responsables: Óscar Acosta (Director). Fundada por Óscar Acosta. Editorial Nuevo Continente.

Periodicidad: Publicación mensual. Número 1 de agosto de 1965. Se publicó hasta el año 1985. Tegucigalpa, Departamento de Francisco Morazán, Honduras.

Consultados: Años 1965-1973. 
Ubicación: Universidad Nacional Autónoma de Honduras (UNAH), signatura: 800.- Casa particular de Óscar Acosta (Falta por vaciar el vol. 76-96).- Hemeroteca Nacional "Ramón Rosa", signatura: 2 y 9.

\section{Asociación de Prensa Hondureña}

APH: Órgano de la Asociación de Prensa Hondureña.

Responsables: Alejandro Castro h. y Santos Juárez Fiallos (Fundadores), Claudio Barrera (Director), Raúl Gilberto Trochez (Redactor administrativo), Rosa Carías García (Asistente), Nora Landa Blanco (Redactora), Ricardo Ragazzone Lara (Redactor), Roberto M. Sánchez (Redactor), Francisco Sánchez (Redactor), Arturo López Rodezno (Colaborador artístico), Benigno Gómez (Colaborador artístico).

Periodicidad: Publicación mensual. Número 1 de noviembre de 1968. Tegucigalpa, Departamento de Francisco Morazán, Honduras.

Consultado: Años 1968-1969.

\section{Revista del Archivo y Biblioteca Nacional}

Responsables: Licenciado Esteban Guardiola (Director).

Periodicidad: Publicación quincenal, número 1, del 10 de noviembre de 1904. Posteriormente mensual hasta noviembre de 1936. A partir de diciembre-enero de 1937 bimensual. Tegucigalpa, Departamento de Francisco Morazán, Honduras.

Consultados: años 1905, 1907, 1927, 1928, 1932-1934 y 1936-1937.

\section{Ateneo de Honduras}

Responsables: Froylan Turcios (Director), Rómulo E. Durón (Redactor), Esteban Guardiola (Redactor), Salatiel Rosales (Redactor), Samuel Laínes (Redactor) y Carlos Zúñiga Figueroa (Director artístico).

Periodicidad: Publicación mensual. Número 1 del 22 de octubre de 1913. Tegucigalpa, Departamento de Francisco Morazán, Honduras.

Consultado: años 1914 y 1923.

Revista de la Universidad [Nacional Autónoma de Honduras]

Responsable: Rómulo E. Durón (Director) y Alberto A. Rodríguez (Administrador). Periodicidad: Publicación mensual. Número 1 del 15 de enero de 1909. Tegucigalpa, Departamento de Francisco Morazán, Honduras.

Consultado: Año 1910.

Ubicación: Universidad Nacional Autónoma de Honduras (UNAH), signatura: 000.- Hemeroteca Nacional "Ramón Rosa", signatura: 4.

\section{Sectante}

Sectante (Sectín Actuante).

Responsable: Ministro, Teniente Coronel y Abogado Efraín L. Gonzales, bajo el patrocinio de la Secretaría de Cultura, Turismo e Información. 
Periodicidad: Bianual. Número 2 de enero de 1976 es el más antiguo. Tegucigalpa, Departamento de Francisco Morazán, Honduras.

Consultado: Número 2 (julio-diciembre) 1977.

Ubicación: Hemeroteca Nacional "Ramón Rosa", signatura: 2. 